\title{
Könyvtárak - belépési pontok a digitális világba
}

Az új típusú keresőrendszerek megjelenését a változó környezet, a változó keresési szokások indokolták. Megértéséhez tekintsük át digitális világunkat és ebben a könyvtárak új szerepét!

\section{A digitális világ, a digitális nemzedék}

A következők az egész világon érvényes megállapítások, de most elsősorban Magyarországot nézem az internethasználat és a digitális tartalmak fogyasztása tekintetében. Az internethasználat folyamatosan nő, Magyarországon 2016 júniusában több mint 5 millió fö használta a hálózatot a 15 évnél idősebbek körében. Ez megfelel az európai átlagnak, és magasnak mondható a kelet-közép-európai régióban. Nagy részük $(76,6 \%)$ napi szinten fogyaszt digitális tartalmat. A netezők 69\%-a a 18-49 év közötti korosztályból kerül ki, de a 60 éves kor feletti felhasználók aránya is folyamatosan emelkedik. ${ }^{1} \mathrm{Az}$ internethasználat egyre inkább a mobil eszközökre tevődik át: mobiltelefont, okostelefont, laptopot, táblagépet (tabletet) használunk. Ezek az eszközök mindig kéznél vannak, így folyamatosan információhoz jutunk és információt továbbítunk, miközben a mobilinternet használatával folyamatos az internetkapcsolat.

A fiatalok munkavégzéssel kapcsolatos elvárásai nem ugyanazok, mint a korábbi korosztályoké, amit a munkaadóknak is figyelembe kell venni. Míg évekkel ezelött konferenciákon és tanulmányokban is éles viták voltak arról, mennyire biztonságos a céges környezetben a mobil eszközök használata, addig ma ez már elfogadott. A Cisco 2013-as felmérése szerint (mely nem volt reprezentatív) a hazai munkavállalóknak már $60 \%$-a rendelkezett olyan mobil eszközzel, mellyel képes volt csatlakozni a munkahelyi hálózathoz, és el tudta érni a céges adatokat, alkalmazásokat. ${ }^{2}$ Emellett változik az olvasási, információszerzési kultúra is, amit jól szemléltet az alábbi két, korunkra ható írástudótól származó idézet: „... a könyv az emlékezet és a képzelet meghosszabbítása” (Jorge Luis Borges, aki 1955-1973 között az Argentin Nemzeti Könyvtár igazgatója volt). „Keveredik az olvasás és az információszerzés” (Esterházy Péter).

A fiatalok nemcsak a munkavégzéssel kapcsolatban gondolkodnak másképp, hanem másképp jutnak információhoz is. A lexikonok, könyvek helyett az

${ }^{1}$ Gyorsjelentés a hazai-internetezőkröl. Forrás: Q2 gyorsjelentés a hazai internetezőkről. Gemius, 2016. augusztus 4. Forrás: http://hirlevel.egov.hu/2016/08/07/gyorsjelentes-a-hazai-internetezokrol (2016. augusztus 4.)

${ }^{2}$ A munkahelyeken is terjed a mobil eszközök használata. Forrás: https:/itcafe.hu/hir/cisco mobil_eszkozok_byod_felmeres.html (2016. augusztus 4.) 
internet használatát előnyben részesítő „,internetfüggő” diák nyilvánvaló konfliktusforrás a „maradi” oktatási rendszerben. Az ,internetfüggést” nem rossz értelemben használom, hiszen mennyivel egyszerübb az úgyis kézben lévő mobil eszköz keresőjébe (Google, Wikipédia) beírni azt, ami érdekel, amiről többet szeretnénk tudni, és pillanatokon belül megkapjuk a választ - valljuk be, nekünk is, akik nem az internet világában szocializálódtunk. És másképp is kommunikálnak ,... az a természetes, hogy egymás mellett ülünk, szakmai kérdésekről beszélgetünk, és a másik nem csak hozzászól a vitához, hanem gyorsan küld egy grafikont, ami alátámasztja, vagy éppen cáfolja, amit mondtam". ${ }^{3}$

A szakirodalom a digitális készségek alapján csoportokat alakított ki, melyek a születési dátumot figyelembe véve határozzák meg kinek milyen a viszonya a digitális világgal. ${ }^{4}$ Ez alapján az 1925-1945 között született generáció alkotja az építők vagy a veteránok csoportját, az 1946-1964 között születettek a Baby boom nemzedéket, az X generációhoz az 1965-1979 között született korosztályt sorolják. Az Y generációt az 1980-1995 között született korosztály, a Z generációt az 1996-2009 között született korcsoport (ők a digitális bennszülöttek) alkotja. Az alfa generáció a 2010 után született nemzedék, ők azok, akik most kerülnek iskolás korba.

A világháló hatalmas információs tudásbázisában nehéz eligazodni, „... miközben a legtöbb website tökéletesen ismeretlen, van néhány olyan centrum, mint a Google, az Amazon vagy a Yahoo!, amely linkek millióit gyüjti egybe". ${ }^{5}$ Sokszor nem egyszerü felismerni a hiteles forrásokat, meg kell tanulni jól keresni a rendelkezésünkre álló információhalmazban, jól használni és továbbadni a szerzett tudást. Nekünk, akik nem beleszülettünk az internethasználatba, és több a korábbi, nem interneten szerzett tudásunk, talán egyszerübben szelektálunk a világhálón megjelenő tartalmak között. Tudjuk, hogy nem minden információ származik hiteles forrásból - az egyének mellett a könyvtáraknak is felelösségük van az Y, a Z és az alfa generációk „okosításában”. A digitális nemzedék nem érti, miért tiltják az oktatók a Wikipédia használatát. Szerintük, ahogy bárki készíthet weboldalt, online újságot, a Wikipédiához is bárki hozzáadhat újabb információt, hiszen ez is egy közösségi forrás. Azt hiszik, hogy a Google keresés találatai közül az elsők a legnépszerübbek és egyúttal a legmegbízhatóbbak is. „A legfontosabb azonban, hogy ne hagyd abba a kérdezést. A kíváncsiság nem véletlenül van a világon." - Einstein híres mondása az internet világában is érvényes és időszerü, hangsúlyozása talán valamennyi fent megfogalmazott kritikai észrevételnél fontosabb. Ennek szellemében, ha az idősebb korosztály szót

$3 \mathrm{Az}$ információ hatalom, mégsem használjuk. Forrás: http:/hvg.hu/vallalat_vezeto/ 20160804_digitalizacio_hatekonysagnoveles (2016. augusztus 4.)

${ }^{4}$ Generációs elméletek. Forrás: http://janus.ttk.pte.hu/tamop/tananyagok/digitalis_nemzedek/ genercis_elmletek.html (2016. augusztus 4.)

${ }^{5}$ Barabási Albert-László: Villanások. A jövő kiszámítható. Budapest, Nyitott Könyvmühely, $2010.335 \mathrm{p}$. 
akar érteni a digitális bennszülöttekkel, akkor a „digitális bennszülöttek nyelvén és igényeik szerint kell megfogalmazni és kifejezni azokat az ismereteket, információkat, amiket szeretnénk megosztani" ${ }^{6}$ velük.

Változnak a keresési szokások, Barabási-Albert László szerint „Manapság villanásos keresési eljárásokkal" keresünk. Kutatások, elemzések vizsgálják a keresési szokásokat, a „,.. tudósok bebizonyítják, hogy egy adott tárgy megtalálására nem a kézenfekvő szisztematikus keresés, hanem egy kicsúcsosodó, megszakításokkal, sőt esetlegességgel operáló stratégia a leghatékonyabb".?

\section{Könyvtárak új szerepe - digitális könyvtár}

Nézzük meg mi a digitális világban a könyvtárak új szerepe, hogy válik a könyvtár digitális könyvtárrá! Az internet terjedése és a digitális nemzedék fentiekben érintett hatásain kívül nagy szerepe van a technológiai fejlődésnek abban, hogy változnak a könyvtárakkal szembeni elvárások. A technológiai fejlődés olyan gyors, hogy ma még elképzelni sem tudjuk, milyen eszközöket fogunk használni pár év múlva. A mobil eszközök, a szoftverek fejlesztése, a nanotechnológia hihetetlen távlatokat ígér. 1959-ben Richard Feynman fizikus még csak elmélkedett a nagyon kicsi gépekről, ma már kísérleteznek nanobotokkal (nanométer hosszúságú robotok), melyek az emberi testben keringve folyamatosan kommunikálni tudnak az okoseszközökkel. ${ }^{8} \mathrm{Az}$ új fejlesztések, az új eszközök már a könyvtárakban is megjelentek, rendelkezésre állnak, és segítik a kutatók munkáját. Ilyen például a fordítóceruza vagy a digitális szövegkiemelő, míg a szabad polcon elhelyezett könyvek közötti eligazodást segítheti a digitális könyvjelző. Ismerjük már a drónokat, lehet kísérletezni könyvtári alkalmazással, például drónt használni könyvek kiszállítására. ${ }^{9}$ Alkalmazzák már az igény szerinti nyomtatást: könyvesboltok is kínálnak ilyen szolgáltatást, de könyvtárban a könyvtári állományból is előállíthatunk digitális másolatot a szerzői jogi szabályozás betartásával. Egyelöre ez utóbbi szolgáltatás iránt korlátozott a fizetőképes kereslet, ezért kevéssé tekinthetők sikeresnek az ilyen irányú próbálkozások. A könyvtár további szolgáltatásokat kínálhat speciális mobil applikációk segítségével, ilyen például az az olvasó alkalmazás, amivel hozzáférhetünk a MEK könyveihez, vagy az e-könyv kölcsönzés kezelése, figyelmeztetés a kölcsönzött könyv lejáratára, az elektronikus források elérése a könyvtári kártya alapján, a könyvtári katalógus mobil eszközökre való adaptálása stb. A könyvtárnak - alkalmazkodva a megváltozott használói szokásokhoz - mind az egyéni, mind a közösségi igények kiszolgálá-

${ }^{6}$ Digitális bennszülött és digitális bevándorló. Forrás: http://janus.ttk.pte.hu/tamop/tananyagok/digitalis_nemzedek/digitlis_bennszltt_s_digitlis_bevndorl.html (2016. augusztus 4.)

${ }^{7}$ Barabási Albert-László: I. m.: 179. p.

${ }^{8}$ Szauer Tamás: Nanobotok és az örök élet. HVG, 38. évf. 2016. 35. sz. augusztus 25. 62. p.

${ }^{9}$ Piotr Kowalczyk: Library of the future. 8 technologies we would love to see. Forrás: http:// ebookfriendly.com/library-future-technologies/ (2016. augusztus 4.) 
sára alkalmasnak kell lenniük: közösségi tereket, kiscsoportos tanuláshoz alkalmas, online foglalással igénybe vehető szeparált helyiségeket egyaránt kell biztosítaniuk. Mivel a tanulás, a kutatás, a munkavégzés már nincs helyhez kötve, egyre népszerübbek a távolról elérhető szolgáltatások (például az elektronikus tartalmakhoz való távoli hozzáférés), ezekkel párhuzamosan a hagyományos funkciók (könyvkölcsönzés, másolatok kérése stb.) egyre inkább háttérbe szorulnak.

$\mathrm{Az} Y$ és a $\mathrm{Z}$ generáció tagjai részben már most jelen vannak a munkaerőpiacon, ezért a könyvtári szolgáltatások tervezésekor pontosan ismerni kell az igényeiket. Választ kell kapnunk arra,

- hogy és hol tanulnak,

- hogy és hol dolgoznak,

- hogy és hol szereznek információt,

- hogy és hol hasznosítják a megszerzett információt.

Az Y és a $\mathrm{Z}$ generáció számára mások a prioritások, mint a korábbi generációk számára. Mobilak, nem helyhez kötöttek, bárhol tudnak tanulni, kutatni, dolgozni (kávézóban is, ha van internet, ha pedig nincs, használja saját mobilinternetét, akár külföldröl is), nincsenek egész nap a munkahelyen. Ma már olyan cégek is vannak, ahol a dolgozónak asztala sincs, mindenki oda ül, ahol hely van, illetve ahogy a projekt szerinti csapatmunka megkívánja. Érdemes elolvasni a Z-generáció álommunkahelyéről szóló, nemrég megjelent cikket a HVG weboldalán. ${ }^{10} \mathrm{~A}$ cikkben megfogalmazott munkakörnyezet biztosítása valószínúleg nem elsősorban a könyvtárakban jelenik meg, de érdemes készülni rá.

Megváltozott a kutatási, tanulási folyamat. A nyomtatott világában a könyvtár a tanulás, kutatás fontos helye volt, a könyvtárban elérhető dokumentumokból dolgoztak, szereztek új információt a kutatók, a könyvtár köré szervezték a feladataikat, munkafolyamataikat, a könyvtár korlátozottan volt kapcsolatban a teljes folyamattal. A digitális világban ez megváltozott. A könyvtárnak kell alkalmazkodnia a kutatók és tanulók munkafolyamataihoz. A munkafolyamatok információs forrásokat generálnak és használnak. A világháló hozzájárul a tudomány zárt struktúráinak nyitottabbá tételéhez. Beszélünk már open access folyóiratokról, nyitott tudományról (open science), nyílt forráskódú (open source) programokról. ${ }^{11} \mathrm{~A}$ könyvtár már nem az egyedüli hely, ahol információhoz juthatunk. Az információszerzés szükségessége nem korlátozódik a tanulás időszakára, illetve a munkában töltött évekre. Az egész életünk során tanulunk, ebben a gyorsan változó világban az „érvényes tudás” felezési ideje jelentős mértékben csökkent, szükség is van az ismeretterületek közti mobilitásra. Az információszerzésre kitágult a tér: az internet otthonról, a könyvtárakból és az egyéb közösségi helyekről is elérhető.

${ }^{10}$ Ilyen a Z-generáció álommunkahelye. Forrás: http://hvg.hu/brandchannel/HVG_konferencia_20160825_Ilyen_a_Zgeneracio_alommunkahelye (2016. augusztus 4.)

${ }^{11}$ Nyíri Kristóf: Nyitott tudomány, nyitott oktatás. Forrás: http://www.hunfi.hu/nyiri/OKTK 2000.htm (2016. augusztus 4.) 
A kutatás és a tanulás munkafolyamatainak megfelelően célszerủ átalakítani a szolgáltatásokat és új információforrásokat beszerezni. A folyamatok során a kutatók felhasználnak és létre is hoznak információforrásokat. A könyvtárak infrastruktúrát, elérhető forrásokat, online szolgáltatásokat biztosítanak, elektronikus forrásaikat repozitóriumokban archiválják. A könyvtári katalógus a dokumentumok bibliográfiai (meta)adatait tartalmazza, melyek már az online katalógusban is kapcsolódtak másik bibliográfiai vagy authority adathoz, a digitalizált dokumentum a nyomtatott leírásához. Az authority adatok tartalmaznak névváltozatokat, írói álneveket, vagyis utalásokat a besorolási elemhez, tartalmazhatnak linket különböző névterekhez (MTA AAT, VIAF, MTMT stb. adatbázisokhoz). A digitális világban a strukturált adatok kapcsolódásainak kezelése a szabványos web technológiákon alapszik, ez a szemantikus kereséshez elengedhetetlen. A jövőben ennek egyre nagyobb szerepe lesz, hiszen nem a katalógus készítőjének kell megadni a kapcsolódásokat, hanem a helyesen bevitt adatok alapján a web technológia révén automatikusan létrejön a kapcsolat. ${ }^{12}$ A pontosságnak, az adatok helyességének éppen ezért még fontosabb jelentősége lesz a feldolgozásban. Tekintettel az új könyvtári szerepre, érdemes átgondolni és mélyíteni a könyvtárak közötti együttműködést, hiszen a kapcsolt adatok karbantartása is gazdaságosabb, ha a könyvtárak együttmüködésén alapszik.

Célszerü a könyvtáraknak is jelen lenniük a közösségi hálón, mivel az internethasználók számára ez a kommunikáció egyik fontos eszköze. A könyvtári világot (a könyvtárban felhalmozódott tudást, az adatokat) az egész webes világ (World Wide Web) részévé kell tenni!

\section{Új keresési, kutatási (discovery) szolgáltatások}

A könyvtári szolgáltatások fejlődésének első állomása az integrált könyvtári rendszerek megjelenése volt, már több mint 30 éve hogy piacra kerültek az első szoftverek. Ahogy változtak a keresési szokások, úgy indult el a fejlesztés a metakereső rendszerek irányába, később ezekhez a rendszerekhez linkfeloldó szolgáltatásokat is fejlesztettek. Ez lehetővé teszi a kereséskor talált dokumentum teljes szövegü elérését, ha az releváns. A linkfeloldó a tudásbázis alapján ellenőrzi, hogy a könyvtár melyik szolgáltatóval áll kapcsolatban, és hogy ott az adott dokumentum elérhető-e: ezen információk szerint kapcsol a szolgáltatói oldalra. A következő fejlődési állomás a discovery rendszerek megjelenése volt. Az új keresési elvárásoknak megfelelően a felfedező keresés, a könyvtári források egy időben való keresése került előtérbe. A discovery rendszer esetében mindenképpen célszerủ a korábbi OPAC kiváltása, mivel minden OPAC funkció integrálva van bennük, kapcsolódnak az integrált könyvtári rendszerhez.

${ }^{12}$ Axel Kaschte: Linked open data on its way into next generation library management and discovery solutions Forrás: http://leo.cineca.it/index.php/jlis/article/view/5492 (2016. augusztus 4.) 
A discovery (egységes magyar elnevezést még nem sikerült találni, de pl. a Budapesti Corvinus Egyetem Egyetemi Könyvtár „Szuperkereső”-nek nevezi) szolgáltatások jellemzői:

a) a felfedező keresés (discovery): használóközpontú keresés, a kutatóra bízzuk, mit és hogy akar keresni;

b) az egyablakos keresés, s mellette lehetőség van a gyakorlottak számára több szempont szerinti keresésre is;

c) a könyvtár minden forrásában egyszerre lehet keresni, ugyanakkor lehetőség van speciális keresésre (például adott szerző adott mủvére keresni, vagy kizárólag a kölcsönözhető állományra korlátozni a keresést) a kiválasztott katalógusban, adatbázisban;

d) a teljes szövegü tartalmak elérése az intézmény által előfizetett adatbázisokban, intézményi repozitóriumokban;

e) a kapcsolt adatok: új technológia megjelenése.

A felfedező keresés használóközpontú, elsősorban a témára való keresésnél élvezhetjük az előnyeit. Ha azonban nem korlátozzuk a keresést egy adott forrásra, akkor olyan információk is elérhetők lesznek, melyek az addig még nem ismert adatbázisokban érhetők el. Fontos elv, hogy a könyvtárnak mindent fel kell kínálnia, ami elérhetö, és majd a használó válogat - hiszen ő tudja, mire van szüksége. A discovery szolgáltatás ugyanakkor azt is lehetővé teszi, hogy a keresés során újabb és újabb, számára értékes információt fedezzen fel. Az egyablakos keresésnél az egyszerre kereshető források a könyvtári konfigurálástól függenek. Kialakítható rádiógombokkal vagy lenyitható menüben való választással, hogy milyen forrásban kereshetünk. Az adott könyvtár használóinak szokása szerint érdemes meghatározni az egyszerre, egy időben kereshető adatbázisok csoportját. Néhány lehetséges példa: Könyvtári állomány nyomtatott és elektronikus Elöfizetett, licencelt elektronikus - Hozzáférhetö - Minden együtt - Folyóiratok csak nyomtatott, vagy nyomtatott és elektronikus együtt - E-könyvek - Olvasó központú beszerzéssel (PDA) elérhető gyüjtemény(ek) - Osztott források stb. A teljes szövegü tartalmak elérhetők a találati halmazból, a rendszer mögötti tudásbázis alapján a releváns szolgáltatónál. A távoli elérést a szolgáltatók sokszor egyéni bejelentkezéshez kötik, az egyetemek belső hálózati elérésként teszik lehetővé az egyetemi polgárok (hallgatóik, oktatóik) számára a használatot.

A discovery rendszer elemei:

a) a felhasználói felület, mely többé-kevésbé testreszabható;

b) a linkfeloldó, mely a teljes szövegü elérést biztosítja;

c) a közös index, ami lehetővé teszi az elérhető források egy időben történő keresését, így a keresés gyorsabb, a különböző forrásokból származó tételek megjelenítése egységes felületen, egységes adatokkal történik; 
d) a könyvtári online katalógus elérése, ami lehetővé teszi a meglévő példányok ellenőrzését, előjegyzését, a kölcsönzés lejáratának kontrollálását stb. (bizonyos szolgáltatások csak a bejelentkezett használók számára biztosítottak);

e) API-kon keresztül külső források, egyéb szolgáltatások érhetők el. A közös index létrehozásának vannak korlátai: az egyes források szolgáltatói engedhetik vagy éppen tilthatják a közös rendszerbe való indexelést. A közös indexben a kiadóktól és a szabad hozzáférésü és intézményi repozitóriumokból származó metaadatok és a teljes szöveg elérhetősége, az Abstracting and Indexing (A\&I) források adatai, valamint a könyvtári menedzsment rendszerből a bibliográfiai és példányadatok találhatók. Amennyiben nincs lehetőség a tényleges közös index létrehozására, a virtuális közös index a megoldás: ebben az esetben is tudjuk a különböző forrásokat egyszerre keresni és egy találati halmazban megjeleníteni, azonban ilyenkor a keresés kicsit tovább tart.

A piacon elérhető nyílt hozzáférésű programokon alapuló, illetve kereskedelmi forgalomban kapható discovery rendszer is. ${ }^{13}$ Kereskedelmi forgalomban kapható a Primo és a Primo Central Index (ExLibris) ${ }^{14}$, az Ebsco Discovery Service (Ebsco EDS) ${ }^{15}$, a Summon (ProQuest) ${ }^{16}$ és a WorldCat (OCLC). Nyílt forráskódú programon alapul a VuFind. ${ }^{17}$ Ezekben az alkalmazott technikák a szabványokat vagy ajánlásokat követik, így biztosított a fejlesztésük, a technológiai változások követése. ${ }^{18} \mathrm{Az}$ indexek aktualizálása OAI-PMH alkalmazásával vagy batch feltöltéssel történik. A kereső platformhoz a nyílt forráskódú Apache Solr, a weboldal kialakításhoz PHP programozási nyelvet, a találatok rangsorolására relevancia rangsorolást használnak. Az egyes rendszereknél különböző relevancia rangsorolásokat dolgoztak ki. Ezeket a használó általában nem állíthatja át, a rendszerek implementálásánál kerül meghatározásra, hogy a bonyolult algoritmusban milyen mezők, paraméterek játszanak szerepet. Az adatcserét szabványos protokollal végzik, az adatkapcsolatokat automatikusan építi fel a rendszer. Kapcsolt adatként jelenik meg például a találati listában a könyvborító, amit a Google Books szolgáltatás biztosít a Google Könyvek adatbázisából ISBN alap-

${ }^{13}$ Discovering What Works: Librarians Compare Discovery Interface Experiences Forrás: http://reviews.libraryjournal.com/2011/12/reference/discovering-what-works-librarians-comparediscovery-interface-experiences/ (2016. augusztus 4.)

${ }^{14}$ Ismertetés: http://www.exlibrisgroup.com/category/PrimoCentral (2016. augusztus 4.)

${ }^{15}$ Ismertetés: https://www.ebscohost.com/discovery (2016. augusztus 4.)

${ }^{16}$ Ismertetés: http://www.proquest.com/products-services/The-Summon-Service.html (2016. augusztus 4.)

${ }^{17}$ Ismertetés: http://vufind-org.github.io/vufind (2016. augusztus 4.)

${ }^{18}$ NISO Open Discovery Initiative. Forrás: http://www.niso.org/apps/group_public/download.php/14487/future_library_resource_discovery.pdf); NISO RP-19-2014, Open Discovery Initiative: Promoting Transparency in Discovery http://www.niso.org/apps/group_public/download. php/14820/rp-19-2014_ODI.pdf (2016. augusztus 4.) 
ján. Hasznos szolgáltatás a szerzők adatainak elérése is a különböző névterekben, hiszen így a használó a keresése kapcsán további információkhoz jut.

Az eddigiek alapján látjuk, miért fontos a felfedező keresés, miért indultak el a fejlesztők ebbe az irányba. Az információhoz jutás a tanulás alapja, s az új keresési szokások a tanulási folyamatra építenek. Az induló keresés a témával kapcsolatos irodalom felfedezését teszi lehetővé. Innen továbblépve, beleolvasva a metaadatokba, vagy a teljes szövegủ tartalomba, további információhoz jutunk, ötleteket kapunk a további kereséshez. Utána már szisztematikusan kezdünk kutatni az új ismeretek, kulcsszavak felhasználásával. Ha egy konkrét, ismert információ (például a dokumentum címe) alapján keresünk, nem szükséges a minden forrásban történő keresés, célszerü ekkor az adott keresőcsoportot (könyvtár gyüijteménye, cikk keresése stb.) kiválasztani. A témára keresés már indokolja a mindenben keresés választását, hiszen sokkal nagyobb a merítés, felkínáljuk a kutatónak az összes elérhető forrásunkat, és rábízzuk, hogy ő szelektáljon és válassza ki a számára releváns irodalmat.

A könyvtárak számára új úgy alkalmazkodni a használók igényeihez, hogy nem kiszolgálják, hanem segítik a hallgatókat, kutatókat a leghatékonyabb információhoz jutásban. Ennek megfelelően alakítják a szolgáltatásokat, felkínálják a könyvtárban elérhetö összes forrást oly módon, hogy a használók gyorsan és könnyen jussanak a számukra releváns információhoz.

\section{Rezümé}

Az új típusú keresőrendszerek megjelenését a változó környezet, a változó keresési szokások indokolják. Az internethasználat folyamatosan nő: Magyarországon az európai átlagnak megfelelő, sőt a kelet-közép-európai régióban magasnak mondható, napi szintü a digitális tartalmak fogyasztása. A digitális nemzedék másképp gondolkodik a munkavégzéssel kapcsolatban, mások a prioritások, és másképp is kommunikál. A könyvtáraknak figyelembe kell venniük a digitális nemzedék igényeit, keresési szokásait. Az új típusú discovery (felfedező) szolgáltatások egységes felületen kínálják az elérhető forrásokat, a tanulás a felfedező keresés egyik fontos eleme. Témára keresésnél az online katalóguson kívül az intézményi repozitóriumból és az előfizetett forrásokból egyszerre kapjuk meg a releváns találatokat. A jelenleg használatban lévő discovery rendszerek a Primo, az EBSCO EDS, a Summon, az OCLC WorldCat és a VuFind. A könyvtárnak alkalmazkodni kell a használói igényekhez, nem kiszolgálni, hanem segíteni kell őket a leghatékonyabb információhoz jutásban.

\section{Libraries - Entry Points to the Digital World}

Academic libraries are no longer the only choice for students and researchers to go for information. In the digital world blogs and wikis, Facebook and YouTube create new 
types of content. The digital natives have different needs, they search, learn, work and communicate in a different way. As the search behaviors changed, discovering became the new trend. The discovery systems make accessible all the materials that a library can offer (print and electronic) through a single search box. Libraries have to give up some traditional catalogue functionalities and offer a unified view of all institutional data whether it comes from the online catalogue or the institutional repository or a licensed resource. Libraries have to know what topics users are searching and how they search and have to introduce new services based on the new trends.

NASZÁDOS EDIT

szakmai tanácsadó

MTA Könyvtár és Információs Központ 